\title{
Human Health Risk of Polychlorinated Biphenyls in Some Brackish and Marine Fish Species from Ondo South-West Nigeria
}

\author{
Yakub, A. S., Bassey, B. O., Balogun, K. J., Igbo, J. K., Ajani, G., Bello, B., Abiodun, O., Olapoju, O., \\ Nosazeogie, E. O. and Izge, M. A. \\ Department of Biological Oceanography, Nigerian Institute for Oceanography and Marine Research (NIOMR), Victoria Island, \\ Lagos Nigeria. P.M.B. 12729
}

*Corresponding author: Bassey BO, Department of Biological Oceanography, Nigerian Institute for Oceanography and Marine Research (NIOMR), Victoria Island, Lagos Nigeria. P.M.B. 12729

\section{ARTICLE INFO}

Received: 画 August 21, 2020

Published: 幽 September 10, 2020

Citation: Yakub, A. S., Bassey, B. O., Balogun, J. K., Igbo, J. K., Ajani, G., Bello, B., Abiodun, O., Olapoju, O., Nosazeogie, E. O. and Izge, M. A. x. Human Health Risk of Polychlorinated Biphenyls in Some Brackish and Marine Fish Species from Ondo South-West Nigeria. Biomed J Sci \& Tech Res 30(2)-2020. BJSTR. MS.ID.004928.

Keywords: Polychlorinated biphenyls; Fish; Risk assessment

\begin{abstract}
Globally aquatic environment polluted with polychlorinated biphenyls (PCBs) poses health risk to humans via consumption of its aquatic resources. This study evaluated the polychlorinated biphenyls in brackish and marine fish species and its associated health risk through the consumption of fish from Ondo coastal waters. The health risks were assessed using a risk quotient (RQ) of the fish consumption. A total of ten (10) fish samples were collected from April - December 2018, analyzed, identified and quantified using gas chromatography-mass spectrophotometer (GC/MS) for PCBs. Twenty-eight (28) PCB congeners were screened in the fish samples using standard methods. The mean levels of indicator PCBs ranged from $3.70 \mathrm{ng} / \mathrm{g}$ ww (Arius heudeloti) to $8.60 \mathrm{ng} / \mathrm{g}$ ww (Sphyraenapiscatorum) and Dioxin-like PCB ranged from $0.20 \mathrm{ng} / \mathrm{g} \mathrm{ww}$ (Pentanemusquinquarius) to $6.21 \mathrm{ng} / \mathrm{g} \mathrm{ww}$ (Tilapia sp). The total PCB levels in the fish were relatively below $1000 \mu \mathrm{g} / \mathrm{kg}$ by WHO/FAO guideline. The Estimated daily intake and risk quotient were below 1 which implies no associated health risks in humans due to the intake of PCB contaminants via fish consumption.
\end{abstract}

\section{Introduction}

Polychlorinated biphenyls (PCBs) are synthetic chemicals consisting of 209 isomers classified as persistent organic pollutants (POPs) [1]. Polychlorinated biphenyls (PCBs) are a class of aromatic chemical compounds in which some or all hydrogen atoms attached to the biphenyl ring are substituted by chlorine atoms $(\mathrm{m}+\mathrm{n}=$ 1-10). They can bioaccumulate easily into tissues of aquatic biota and sediment, causing serious damage to the aquatic ecosystems [2]. The main source of PCBs compounds in humans is via dietary fish, which tends to accumulate by direct absorption through the gills, exposure to contaminated sediments, and consumption of insects/ other forms of macroinvertebrates and smaller fish [1]. PCBs have basic resistance to acids, bases as well as heat, and as such are utilized extensively for insulating materials in electrical equipment, heat transfer fluids and as lubricants [3]. Global concerns over the toxicity of PCBs in the aquatic environment and its classification as Persistent Organic Pollutant (POP) led to the ban by the United States Congress in 1979. The key properties of PCBs are environmental stability, biological persistence and lipophilicity which facilitate bioaccumulation along the food chain in a complex manner [4].

Humans are exposed to POP contaminants in several ways: mainly via food ingestion, inhalation, though outdoors and indoors [5]. PCBs are regulated by the European Union, WHO and FAO, as to the level of PCBs present in our food even at low levels. Some of the reported effects of PCBs in humans include skin discoloration, liver dysfunction, reproductive defects, dermatitis, dizziness, and endocrine disruptors in exposed humans [6]. Specific congeners may be monitored in an aquatic environment as suggested by the Stockholm Convention and International Council for the Exploration of the Seas-7 (ICES-7) on POPS which recommended 
the measurement of seven indicator PCB congeners (PCB-28, PCB-52, PCB-101, PCB-118, PCB-138, PCB-153, and PCB-180) to characterize contamination by $\mathrm{PCBs}$ in any environment. One of these seven, PCB118, is classified as a dioxin-like PCB. The six nondioxin-like (NDL) PCBs (PCB nos. 28, 52, 101, 138, 153, 180) used as indicators are representative of the congeners used in the PCB mixtures in the past and of the PCBs found in the environment [2]. In aquatic organisms, most studies have reported on PCBs in the muscles of fish (Baeyens et al., 2007). Thus, fish serve as a crucial constituent of human diets which increases the intake of omega-3 fatty acids which in turn lowers cholesterol, cancer risks, and blood pressure levels. However, despite the beneficial aspects of the consumption of fish, it may contain contaminants such as PCBs or other forms of pollutants. Hence this study underscores the potential uptake of PCBs in fish and its associated health risk via consumption by human from Ondo South West Nigeria.

\section{Materials and Methods}

\section{Study area}

The study area lies in $6^{\circ} 21^{\prime} 1.6^{\prime \prime} \mathrm{N}$ latitude and $4^{\circ} 48^{\prime} 11.8^{\prime \prime} \mathrm{E}$ longitude which falls within the transgressive mud beach zone of the Nigerian coastline. The area lies east of the West African Lagoon system and on the western Flank of the Niger Delta Basin. The general stratigraphy of Ondo State coast therefore differs from that of the Niger Delta by having about $60 \mathrm{~m}$ mud overlying the Benin sands [7]. The fish species were collected from the Igbokoda fish landing site located in Ilaje local government area, Ondo state Nigeria. The community is vastly known for their fishing activities both inland and extensively into the sea via Mahin Lagoon. The GPS coordinate of the sampling location is presented in Figure 1.

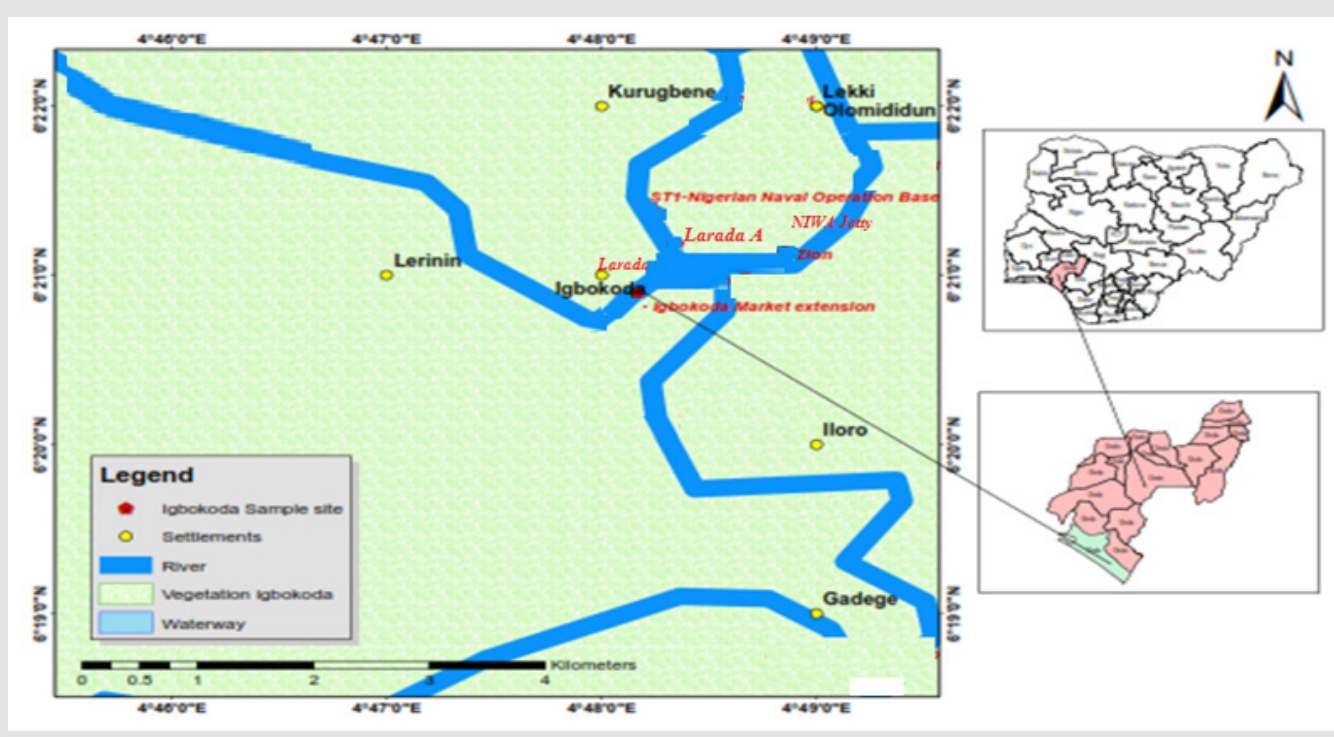

Figure 1: Map of the Igbokoda fish landing site, Ilaje Ondo State.

\section{Sampling Procedure}

The fish species were collected from fisher folks at the Igbokoda fish landing site, Ondo state (April - December 2018). The caught fish species from the sea and brackish waters were collected and stored in an ice container before transporting to the laboratory and stored at a temperature of $-20^{\circ} \mathrm{C}$ until ready for further analysis. The identified fish species used for the study were Pseudotolithus senegalensis, Arius heudeloti, Cynoglossus senegalensis, Galeoides decadactylus, Mugil cephalus, Penaeus notialis, Pentanemus quinquarius, Sardinella eba, Sphyraena piscatorum and Tilapia (Black jaw).

\section{Analytical procedures and Methods}

Determination of PCBs in environmental samples consisted of 3 main steps:

a. Extraction, b. Purification/fractionation of the extract and

c. Chromatographic separation, identification/quantification.

Twenty eight (28) PCB congeners, \#8, \#18 \#28, \#44, \#52, \#60, \#77, \#81, \#101, \#105, \#114, \#118, \#123, \#126, \#128, \#138, \#153, \#156, \#157, \#167, \#169, \#170, \#180, \#185, \#189, \#195, \#206 and \#209 were screened in the fish samples from Ondo Inland waters. The analytical standards ( $>98 \%$ purity) were used to prepare fortification and standard solutions. The extracted samples were subjected to gas chromatography for identification/quantification. The compounds were analyzed using a gas chromatography mass spectrophotometer (GC/MS).

\section{Statistical Analysis}

The statistical analysis of the data was based on the variation of average values by ANOVA and a significance level of $\mathrm{p}<0.05$ was 
used. When the p-value was lower than 0.05, it was considered statistically significant. All statistical tests were performed using SPSS 22 software.

\section{Dietary Intake Estimation}

Human exposure assessment of PCBs through oral ingestion is generally estimated using the daily intake of the contaminant. The estimated total daily intake (EDI) of the contaminants in a given fish species was calculated as follows [8]

$$
\mathrm{EDI}=\mathrm{C} \mathrm{x} \text { Intake } / \mathrm{BW}
$$

Where EDI is the estimated daily intake (ng/kg body wt./day), $\mathrm{C}$ is the average concentration of measured PCBs (ng/g wet weight), Intake is the daily food consumption of fish $(0.0548 \mathrm{~kg} / \mathrm{capita} /$ day) (FAO, 2014) and BW is the average consumer body weight (70 kg for adult men).

\section{Risk Assessment}

The potential risks of non-carcinogenic effects were evaluated by the risk assessment index known as the risk quotient (RQ). The $\mathrm{RQ}$ is defined as the ratio of daily fish exposure level (EDI) in relation to reference dose (RfD) considering non-carcinogenic effects of the contaminants. The RQ was calculated as follows [9]

$$
\mathrm{RQ}=\mathrm{EDI} / \mathrm{RfD}
$$

where EDI is the estimated daily intake (ng/kg body wt./day); and RfD is the reference dose (ng/kg day). The RfD applied in this study was $20 \mathrm{ng} / \mathrm{kg}$ day [9].

\section{Toxic Equivalency (TEQ)}

Toxic equivalency factors (TEFs) are being developed to assess the potency of polyhalogenated aromatic hydrocarbons, including dioxin-like polychlorinated biphenyls (dl-PCBs) (Table 1). In this study the concentrations of individual dl-PCB congeners are multiplied by their TEFs and the results summed to give a toxicity value expressed in TCDD toxic equivalents (TEQs) through the following equation:

$$
\text { dl-PCB TEQ }=\sum \text { dl-PCBi } \times \text { TEF }
$$

\begin{tabular}{|c|c|}
\hline PCB UPAC No. & TEF -WHO 2005 \\
\hline \multicolumn{2}{|c|}{ Non-ortho substituted PCBs } \\
\hline РCB 77 & 0.0001 \\
\hline РCB 81 & 0.0003 \\
\hline PCB 126 & 0.1 \\
\hline РСВ 169 & 0.03 \\
\hline \multicolumn{2}{|c|}{ Mono-ortho substituted PCBs } \\
\hline РCB 105 & 0.00003 \\
\hline PCB 114 & 0.00003 \\
\hline РСВ 118 & 0.00003 \\
\hline PCB 123 & 0.00003 \\
\hline PCB 156 & 0.00003 \\
\hline РСВ 157 & 0.00003 \\
\hline PCB 167 & 0.00003 \\
\hline PCB 189 & 0.00003 \\
\hline
\end{tabular}

Table 1: PCB Congener Toxicity Equivalent Factors (TEF) (Van den Berg et al., 2006).

\section{Results}

\section{Biometric Data of Fish Sample}

The mean biometric data of the weight, total length and standard length of the fish species are presented in Table 2. The highest mean weight value of $507.00 \pm 3.46$ was observed for Sphyraena piscatorum and lowest value of $4.75 \pm 0.17$ for shrimp (Penaeus notialis). The total and standard lengths observed highest value in Sphyraena piscatorum and lowest in Penaeus notialis respectively. All the fish samples were native to the Mahin Lagoon

\begin{tabular}{|c|c|c|c|}
\hline Fish species & Weight (g) & TL (cm) & SL $(\mathrm{cm})$ \\
\hline Arius heudeloti & $213.48 \pm 27.62^{\mathrm{d}}$ & $28.17 \pm 0.33^{\mathrm{d}}$ & $26.17 \pm 4.21^{\mathrm{c}}$ \\
\hline Cynoglossus senegalensis & $79.90 \pm 28.98^{\mathrm{abc}}$ & $25.60 \pm 2.91^{\mathrm{cd}}$ & $24.58 \pm 4.08^{\mathrm{bc}}$ \\
\hline Mugil cephalus & $103.23 \pm 10.43^{\mathrm{bc}}$ & $22.67 \pm 0.33^{\mathrm{bc}}$ & $17.67 \pm 0.88^{\mathrm{bc}}$ \\
\hline Penaeus notialis & $4.75 \pm 0.17^{\mathrm{a}}$ & $8.67 \pm 0.18^{\mathrm{a}}$ & $7.11 \pm 0.33^{\mathrm{a}}$ \\
\hline Pentanemus quinquarius & $56.19 \pm 6.67^{\mathrm{ab}}$ & $20.28 \pm 0.59^{b}$ & $15.15 \pm 0.94^{\mathrm{ab}}$ \\
\hline Pseudotolithus senegalensis & $104.25 \pm 56.93^{\mathrm{bc}}$ & $21.17 \pm 1.67^{b}$ & $20.17 \pm 4.67^{\mathrm{bc}}$ \\
\hline Sardinella eba & $174.01 \pm 53.48^{\mathrm{cd}}$ & $21.40 \pm 1.16^{b}$ & $21.63 \pm 4.33^{\mathrm{bc}}$ \\
\hline Sphyraena piscatorum & $507.00 \pm 3.46^{\mathrm{e}}$ & $40.83 \pm 0.88^{\mathrm{e}}$ & $45.03 \pm 1.51^{\mathrm{d}}$ \\
\hline Tilapia (Black jaw) & $214.35 \pm 2.23^{\mathrm{d}}$ & $20.97 \pm 0.26^{\mathrm{b}}$ & $16.13 \pm 0.59^{\mathrm{ab}}$ \\
\hline
\end{tabular}
and belonged to different trophic levels.

Table 2: Biometric Data of Fish Samples from Igbokoda fish landing site.

PCBs in fish species: A total of 13 congeners were detected in all fish species- PCB 8, PCB 18, PCB 28, PCB 44, PCB 60, PCB 77, PCB 81, PCB 101, PCB 105, PCB 114, PCB 118, PCB 156, and PCB 157 


\section{Indicator PCBs in Fish Samples}

The mean distribution pattern of the indicator PCBs varied greatly between fish species (Figure 2). Marker PCB congeners PCB- 28, PCB- 118 PCB-101 were significant and bioavailable in the muscles of the Arius heudeloti, Cynoglossus senegalensis, Pentanemus quinquarius, Pseudotolithus senegalensis, Sardinella eba and Sphyraena piscatorum. The PCB- 52, PCB- 138, PCB- 153 and PCB- 180 were below detectable level. The highest concentration was detected in P. notialis with value of $0.0054 \pm 0.002$ in PCB- 28 . For PCB 101, the most prominent concentration was detected in Sphyraena piscatorum with notable value of $0.0035 \pm 0.001 \mathrm{mg} / \mathrm{kg}$ and PCB- 118 was detected in Pentanemus quinquarius with 0.0006 $\pm 0.00001 \mathrm{mg} / \mathrm{kg}$. Statistically, there were no significant differences ( $p>0.05$ ) of the marker PCBs in the muscles of the fish species. The mean levels of total indicator PCB congeners in investigated fish species from the Igbokoda fish landing site of Nigeria estimated daily intake (EDI) and risk quotient (RQ) are shown in Table 3.

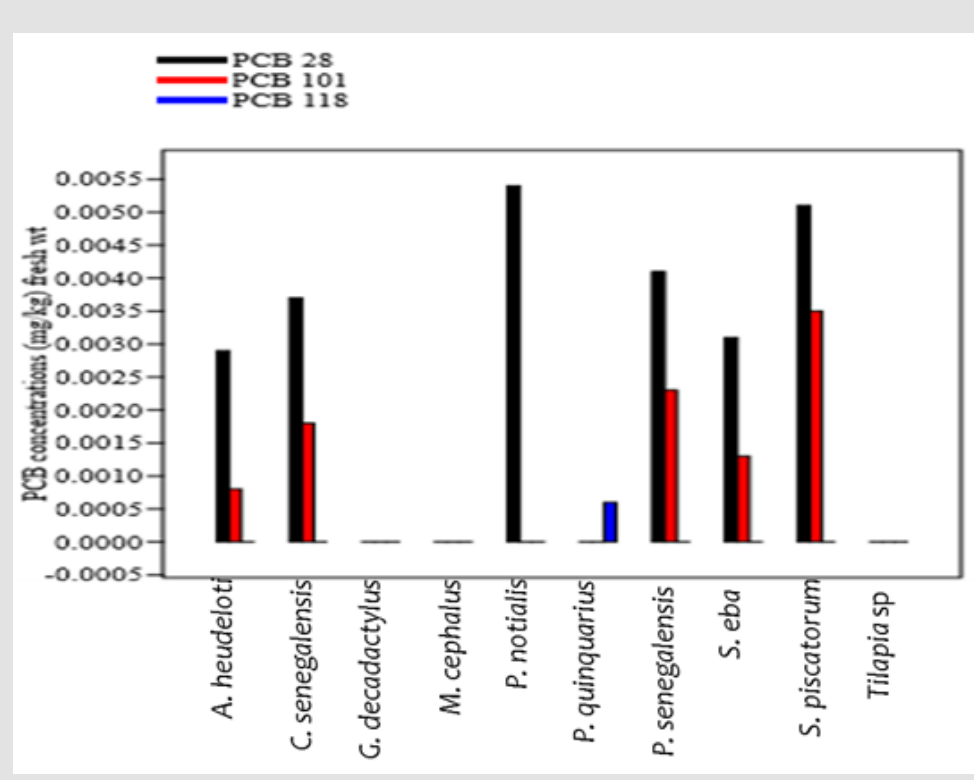

Figure 2: Marker PCBs in Fish species.

Table 3: Levels of total indicator PCBs (ng/g wet weight, mean) determined in fish collected from the Igbokoda fish landing site, estimated daily intake (EDI) and risk quotient (RQ).

\begin{tabular}{|c|c|c|c|c|}
\hline Species & Sum I-PCBs, $n g / g w w$ & EDI & RfD & $\mathbf{R Q}$ \\
\hline Arius heudeloti & 3.70 & 0.003 & 20 & 0.0001 \\
\hline Cynoglossus senegalensis & 5.50 & 0.004 & 20 & 0.0002 \\
\hline P. notialis & 5.40 & 0.004 & 20 & 0.0002 \\
\hline Pseudotolithus senegalensis & 6.40 & 0.005 & 20 & 0.0003 \\
\hline Sardinella eba & 4.40 & 0.003 & 20 & 0.0002 \\
\hline Sphyraena piscatorum & 8.60 & 0.007 & 20 & 0.0003 \\
\hline
\end{tabular}

Dioxin-like PCB Congeners: The concentration levels of the individual seven dioxin-like PCBs (dl-PCBs) congeners (non-ortho PCBs 77, 81 and mono-ortho PCBs 105, 114, 118, 156, 157) were measured. In Table 3 the sum of the seven dl-PCBs congeners (mean values) was presented for the fish species investigated. To compare the results obtained to permissible limits outlined in the EU Council Regulation, the TEQ values and estimated daily intake (EDI) of dl-PCBs were calculated for each fish species and mean values are shown in Table 4. 
Table 4: Sum of seven dl-PCBs (ng/g ww mean and standard error), determined in fish, TEQs (pg TEQ/g ww) and EDI (pg TEQs/ $\mathrm{kg} \mathrm{bw})$.

\begin{tabular}{|c|c|c|c|c|}
\hline Species & $\begin{array}{c}\text { Sum dl-PCBs } \\
\text { (Mean } \pm \text { S.E) }\end{array}$ & $\begin{array}{c}\text { TEQ } \\
\text { (Mean } \pm \text { S.E) }\end{array}$ & EDI \\
\hline Arius heudeloti & $1.59 \pm 0.81$ & $0.00023 \pm 0.0002$ & $3.29 \times 10^{-6}$ \\
\hline Cynoglossus senegalensis & $2.73 \pm 1.02$ & $0.00036 \pm 0.0002$ & $5.07 \times 10^{-6}$ \\
\hline Galeoides decadactylus & $0.09 \pm 0.05$ & $0.000009 \pm 0.00$ & $1.29 \times 10^{-7}$ \\
\hline Mugil cephalus & $3.14 \pm 1.73$ & $0.00057 \pm 0.0005$ & $8.09 \times 10^{-6}$ \\
\hline P. notialis & $0.99 \pm 0.54$ & $0.00003 \pm 0.00$ & $4.29 \times 10^{-7}$ \\
\hline Pentanemus quinquarius & $0.20 \pm 0.13$ & $0.000014 \pm 0.00$ & $2.0 \times 10^{-7}$ \\
\hline Pseudotolithus senegalensis & $1.80 \pm 0.90$ & $0.000241 \pm 0.00$ & $3.44 \times 10^{-6}$ \\
\hline Sardinella eba & $5.13 \pm 0.23$ & $0.0015 \pm 0.00$ & $2.19 \times 10^{-5}$ \\
\hline Sphyraena piscatorum & $0.20 \pm 0.14$ & $0.00001 \pm 0.00$ & $1.42 \times 10^{-7}$ \\
\hline Tilapia sp & $6.21 \pm 3.47$ & $0.0011 \pm 0.001$ & $1.59 \times 10^{-5}$ \\
\hline
\end{tabular}

\section{Discussion}

The mean levels of I-PCBs ranged between $3.70 \mathrm{ng} / \mathrm{g}$ ww (Arius heudeloti) and $8.60 \mathrm{ng} / \mathrm{g}$ ww (Sphyraena piscatorum), calculated as the sum of 2 Indicator PCB congeners. The European Union has recommended a maximum level of $75 \mathrm{ng} / \mathrm{g}$ wet weight, calculated as the sum of the six I-PCBs in the muscle of fish [10]. The results for the sum of I-PCBs (specifically PCB 28 and 101) in all fish species did not exceed this limit. The PCB levels in this study were generally lower at $<1000 \mu \mathrm{g} / \mathrm{kg}$ (The World Health Organization (WHO) and Food and Agriculture Organization of the United Nations (FAO) (2001) guideline is $1000 \mu \mathrm{g} / \mathrm{kg}$ fresh weight). The sum PCB concentration sequence in the fish species of indicator PCBs was Sphyraena piscatorum > Pseudotolithus senegalensis $>$ Cynoglossus senegalensis $>$ P. notialis > Sardinella eba > Arius heudeloti, while the dioxin-like PCB concentration sequence in the fish was Tilapia $s p>$ Sardinella eba > Mugil cephalus > Cynoglossus senegalensis > Pseudotolithus senegalensis > Arius heudeloti > Sphyraena piscatorum > Pentanemus quinquarius > P. notialis > Galeoides decadactylus. To comprehensively evaluate risk exposure, the mean EDIs for these harmful chemicals in each fish species were calculated. Based on the measured concentrations in the fish samples, the daily dietary intake of PCBs was calculated.

The EDI values in our study were lower compared to the EDI of I-PCBs in fish from Black Sea that was calculated between 1.36 and $5.14 \mathrm{ng} / \mathrm{kg}$ bw day through consumption of goby and shad, respectively [5]. The RfD values adopted in this study are the criteria of the USEPA (Environment Agency of the United States) [9]. The RQ values in this study (Table 2) is less than 1, no obvious health risks due to the intake or uptake of contaminants via fish consumption would be experienced. The comparison of our results for TEQ values in fish with those in the literature showed lower levels than the TEQs in sardine from the Spanish Atlantic southwest coast (0.75 pg TEQ /g ww) [11] and lower than those in salmon from the Baltic Sea (12.6 pg TEQ /g ww) [12]. The European Union has set a limit of $3.0 \mathrm{pg} \mathrm{TEQ} / \mathrm{g}$ wet weight in the muscle meat of fish for the sum of dioxin-like PCBs [10]. In our study TEQs of the seven dl-PCBs for all investigated fish species did not exceed this limit. The EDI dl PCBs value in this study were low, while the WHO set for TDI for the sum of TEQ and l-PCB-TEQ of 1-4 pg TEQ kg/ body weight [13], which is comparable with a tolerable weekly intake of $14 \mathrm{pg} \mathrm{TEQ/kg}$ body weight as fixed by the European Union Scientific Committee on Food $[14,15]$.

\section{Conclusion}

The total PCBs (indicator and dioxin-like) levels in the fish samples from Igbokoda fish landing site were relatively low at $<1000 \mu \mathrm{g} / \mathrm{kg}$, below the WHO/FAO guideline of $1000 \mu \mathrm{g} / \mathrm{kg}$ fresh weight. All the RQ values were much lower than 1 , suggesting that consumption of the fish species would not pose any non-cancer risk. However, there is need for periodic biomonitoring of the Mahin lagoon and its adjoining creeks.

\section{Acknowledgment}

The authors are grateful to the Nigerian Institute for Oceanography and Marine Research, Lagos, Nigeria for providing funds for the research and materials used during the study.

\section{References}

1. Jonathan JWA, Woananu Aggor SEE, Adatara P, Adjorlolo Gasokpoh A (2018) Variations of polychlorinated biphenyls (PCBs) levels in the bivalve Galatea paradoxa from Ada, in Ghana, during the dry and wet seasons. J Environ Chem Toxicol 2(2): 48-56.

2. Kampire E, Rubidge G, Adams JB (2015) Distribution of polychlorinated biphenyl residues in several tissues of fish from the North End Lake, Port Elizabeth, South Africa. Creative Commons Attribution Licence 41(4): 559-570.

3. Rudel RA, Seryak LM, Brody JG (2008) PCB-containing wood floor finish is a likely source of elevated PCBs in resident's blood, household air and dust: A case study of exposure. Environ Health 7(2). 
4. (2016) USEPA (United States Environmental Protection Agency) Polychlorinated biphenyls: Learn more about polychlorinated biphenyls (PCBs), USA.

5. Georgieva SK (2016) Estimation of human health risk from polychlorinated biphenyls through consumption of fish from Black sea, Bulgaria. Scripta Scientifica Salutis Publicae 2(2): 22-28.

6. Khim JS, Villeneuve DL, Kannan K, WY Hu, JP Geisy, et al. (2000) Instrumental and bioanalytical measures of persistent organochlorines in blue mussel (Mytilus edilus) from Korean coastal waters. Arch Environ Contam Toxicol 39: 360-368.

7. Fabiyi 00, Oloukoi J (2013) Indigenous Knowledge System and Local Adaptation Strategies to Flooding in Coastal Rural Communities of Nigeria 2(1): 1-19.

8. Yu Y, Wang X, Yang D, Lei B, Zhang X, et al. (2014) Evaluation of human health risks posed by carcinogenic and non-carcinogenic multiple contaminants associated with consumption of fish from Taihu Lake, China. Food and Chem Toxicol 69: 86-93

9. (2000) USEPA (United States Environmental Protection Agency). Guidance for Assessing Chemical Contaminant Data for Use in Fish Advisories. EPA 823B-00-008: 2

10. (2011) European Commission, Commission Regulation (EU) No 1259/2011 of 2 December 2011 amending regulation (EC) no. $1881 / 2006$ as regards maximum levels for dioxins, dioxin-like PCBs and non-dioxin-like PCBs in foodstuffs. Off J of EU. L320: 18-23.

ISSN: 2574-1241

DOI: $10.26717 /$ BJSTR.2020.30.004928

Bassey BO. Biomed J Sci \& Tech Res

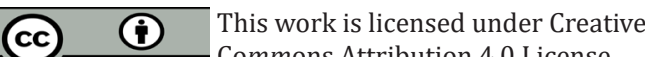

Submission Link: https://biomedres.us/submit-manuscript.php
11. Bordajandi LR, Martin I, Abad E, Rivera J, Gonzalez MJ (2006) Organochlorine compounds (PCBs, PCDDs and PCDFs) in seafish and seafood from the Spanish Atlantic Southwest Coast. Chemosphere 64: 1450-1457.

12. Isosaari P, Hallikainen A, Kiviranta H, Vuorinen PJ, Parmanne R, et al. (2006). Polychlorinated dibenzo-p-dioxins, dibenzofurans, biphenyls, naphthalenes and polybrominated diphenyl ethers in the edible fish caught from the Baltic Sea and lakes in Finland. Environ Poll 141: 213 225.

13. Van Leeuwen FX, Feeley M, Schrenk D, Larsen JC, Farland W, et al. (2000) Dioxins: WHO's tolerable daily intake (TDI) revisited. Chemosphere 40(9-11): 1095-1101.

14. (2001) European Commission Scientific Committee on Food. Opinion on the risk assessment of dioxins and dioxin-like PCBs in food, Europe.

15. Van den Berg M, Birnbaum LS, Denison M, De Vito M, Farland W, et al. (2006) The 2005 World Health Organization reevaluation of human and Mammalian toxic equivalency factors for dioxins and dioxin-like compounds. Toxicol Sci 93(2): 223-241.

$\begin{array}{ll}\text { BIOMEDICAL } & \text { Assets of Publishing with us } \\ \text { RESEARCHES } & \text { - Global archiving of articles } \\ \text { - Immediate, unrestricted online access } \\ \text { - Rigorous Peer Review Process }\end{array}$

